\title{
Main principles in organizing the style and formats of syllabus of an english course in heis
}

\section{Bunafsha RAFIEVA 1 \\ Samarkand Branch of Tashkent State University of Economics}

\begin{tabular}{l} 
ARTICLE INFO \\
\hline Article history: \\
Received December 2021 \\
Received in revised form \\
15 December 2022 \\
Accepted 20 January 2022 \\
Available online \\
15 Fabray 2022
\end{tabular}

\section{Keywords:}

syllabus,

didactic units,

course structure,

resources,

course description.

\begin{abstract}
The given article is devoted to understand the importance of the syllabus of an English course and why this solution can help students. In particular, a well-defined syllabus can be used in every course delivered both online or in a standard face-to-face approach. In this article we will see what the fundamental information to be inserted into this document.
\end{abstract}

2181-1415/C 2022 in Science LLC.

DOI: https://doi.org/10.47689/2181-1415-vol3-iss1/S-pp65-69

This is an open access article under the Attribution 4.0 International (CC BY 4.0) license (https://creativecommons.org/licenses/by/4.0/deed.ru)

\section{Oliy ta'lim muassasalarida ingliz tili kursi sillabusining tartibi va formatlarini tashkil qilishning asosiy prinsiplari}

\footnotetext{
Kalit so'zlar:

sillabus,

didaktik birliklar,

kurs tuzilishi,

manbalar,

kursning tavsifi.
}

\begin{abstract}
ANNOTATSIYA
Ushbu maqola ingliz tili kursi sillabusining ahamiyati va $\mathrm{u}$ talabalarga qanday yordam berishi mumkinligini tushuntirishga bag'ishlangan. Xususan, aniq belgilangan dastur har qanday kursda - ham onlayn, ham standart yuzma-yuz o'qitishda qo'llanilishi mumkin.Ushbu maqolada biz ushbu hujjatga qanday asosiy ma'lumotlar kiritish kerakligini ko'rib chiqamiz.
\end{abstract}

\footnotetext{
${ }^{1}$ Senior teacher of the Languages department, Samarkand Branch of Tashkent State University of Economics. Samarkand, Uzbekistan. E-mail: buna_30@mail.ru.
} 


\section{Основные принципы в организации стиля и форматов силлабуса курса английского языка в вузах}

\author{
Ключевые слова: \\ силлабус, \\ дидактические единицы, \\ структура курса, \\ ресурсы, \\ описание курса.
}

\begin{abstract}
АННОТАЦИЯ
Данная статья посвящена тому, чтобы понять важность силлабуса курса английского языка и как результат может помочь студентам. В частности, четко определенный силлабус может быть использованным в любом курсе, проводимом как онлайн, так и в рамках стандартного очного обучения. В этой статье мы разберём, какая основная информация должна быть добавлена в этот документ.
\end{abstract}

\section{INTRODUCTION}

When we teach face - to - face not a lot of problems can appear, however when it comes to online teaching (Moodle), people not expert in distance learning can erroneously think that in this approach there is not the possibility for a student to interact with his/her instructor [1]. If correctly organized, this can be a real guide for our students independently on the e- course we are considering. Just to better understand this sentence, these solutions can be used for academic course, professional training, and lifelong learning activities and, as we know very well in order to understand why the use of a syllabus is so important.

\section{LITERATURE REVIEW}

The gradual development in language teaching theories is inevitably accompanied by a change in the philosophy, and thus type of syllabus. Likewise, it is worth noting that SD has a rich history of evolution where any newly coined syllabus in essence is a result of emergence of a new trend in language teaching/learning [6]. After having established what to teach, the next phase in syllabus design is a strategy of presentation. The main aim of organizing a syllabus should be to promote learning and not only provide a description of the language. The content should therefore be organized in order to facilitate both learning and teaching. The syllabus could be structured on the basis of a gradual move from the more general to the more specific, a statement of a general rule to a statement of specific rules or exceptions, therefore a deductive process. The material could also be organized in the opposite direction, from the specific to the general, an inductive process [7].

ANALYSIS AND RESULTS. Syllabus organization

As discussed in introduction, a good syllabus has to be filled with all the necessary information. This fact can bring us to the mistake to cram it with unnecessary details creating even more confusion in our students. Unfortunately, there is not a precise recipe to be followed to prepare a good syllabus. The types of information to be inserted strongly depend on the course for which the syllabus is prepared. Despite this, we can define some important fields that must be present and we are going to discuss them just to understand what is the final philosophy to be followed in order to learn how to manage this powerful tool [4]. At this point, instead of starting a detailed discussion on the "theory of the syllabus" we can perform a practical exercise taking into account the syllabus developed for English course. As a matter of fact, the syllabus developed for 
this course was prepared with the precise aim to offer a detailed guide for yourself, as trainers, and we, as authors of these lessons, strongly suggest you to use it in a proper way.

\section{SYLLABUS PARTS}

First of all, in the preliminary part of each syllabus we must insert an intuitive table in which we report:

- the name of the course;

- the pre-requisites, i.e. if there are some mandatory (or even suggested) courses that must be followed before starting the study;

- the hours of: lessons, virtual/off line classes and other activities in order to share immediately the commitment requested;

- the hours of suggested self-study;

- the name or names of the instructors of the course.

Obviously, in this list, the "hours of suggested self-study" is an indication that strongly depends on the single student but it is important to give this indication in order to clearly identify the assigned duties or also to compare the course we are presenting with others. After this preliminary indication, we can enter into the details of the course and in particular we have to report:

- Course description;

- Learning objectives;

- Course structure.

As clear, we are now going through the specific structure of the course. Concerning "course description", we have to report here the final aim of our subject together with the description of the macro-arguments. Otherwise, for the "learning objectives", we must report about the abilities that will be acquired at the end of the course. Obviously, these objectives must be clearly indicated following the standards defined in the Bologna process. This assumption is fundamental since only in this way we can have something that not only is clear but that simply permits a comparison with other courses. The last item of the previous list, "course description", gives us a general overview of the structure of the course indicating the division into modules or didactical units together with the time commitment of each single part. After this first fundamental part, we now enter inside the so-called "Topical Outline and Schedule". As the name itself suggests, we should include here the real guide for our students in which we leave the general overview to go through each single argument [3]. As known by any teacher, any course is divided into modules. For each module we indicated the number of weeks normally necessary to efficiently acquire the requested knowledge. Obviously, this part of the syllabus should be divided into section relative to a single module. In every part we should report, in a sort of tree-logic, the sub-unit, i.e. the lessons of the module, and the sub-sub-units, i.e. the arguments of each single lesson.

If, as discussed, the number of weeks is only an indication student depending, this information can be useful to compare different modules with different time indications. Moreover, always comparing different modules using this time indication, we have a course that does not consist in a flat structure in which, before starting the study, every module appears as an identical part of the whole. The last part of the single module table regards the out-of-class activities and the assigned readings. As clear, we are treating this part separately from the previous since before we discussed the in-class duties while now we are treating what the student is expected to study out-of-class. 
Be quiet of an important detail: the "assigned self- study" in this part, which may include: books, additional materials, websites, papers, etc., is specific for this module. This means that here we cannot insert the textbooks of the whole course since these should be reported in the first part relatives to the entire course.

At the end of the syllabus, we can report the instructional material and the references. Moreover, we also suggest indicating the date of the last revision and, optionally, the date of the first release of the document [5]. This information is important for example for courses in which the arguments can change rapidly and the release date indicates the period we are considering (consider for example a law course in which there will be changes in the regulation and is fundamental to know at what version we are referring).

\section{REQUIRED AND ADDITIONAL INFORMATION}

Summarizing what discussed up to now, to have a syllabus able to work as a complete guide for our students it must include: the course;

- a first general part with: general details, objectives, description and structure of

- a detailed part with clear "instructions" for each module together with the time commitment and self-study part.

Obviously, when discussing about a university subject, we can complete our scheme with some additional details [2]. In this context, preparing a syllabus for an academic course, we can add also details that are specific for our university or for the country in which the course is delivered. Just to provide some useful examples we may insert:

- Attendance policy;

- Student tardiness policy;

- Instructional method;

- Library information and resources;

- Details on final exam and assessment criteria;

- Distribution of grade elements.

As written, this is always a not complete list that can be enriched with every detail important for you or for your students.

\section{CONCLUSION}

In this article we discussed the didactical importance that a well-prepared syllabus can have for students. As a matter of fact, the need of a detailed guide can strongly speedup the learning process of our audience defining a clear path and avoiding confusion before and during the study of a course. In this sense, a well -structured syllabus can shepherd our students step-by-step proving them a clear learning path together with suggestions that otherwise they would acquire by themselves with difficulties. The information present in this article may be adapted for every course and every possible student and for this reason they have to be taken into consideration every time we prepare or update our subject.

\section{REFERENCES:}

1. Dede C.J. (1990), The evolution of distance learning: Technology-mediated interactive learning, Journal of research on Computing in Education 22.3: 247-264. 
2. Hillman K. (2005), The first year experience: the transition from a secondary school to university and TAFE in Australia, LSAY research project.

3. de Guzman M., Hodgson B.R., Robert A. and Villani V. (1998), Difficulties in the passage from secondary to tertiary education, Proceedings of the International Congress of Mathematician.

4. Gerdes H., Mallinckrodt B. (1994), Emotional, Social and Academic adjustment of College students: a longitudinal study of retention, Journal of Counselling and Development vol. 72 issue 3.

5. Fontana F. and Martini M. (2016), A powerful learning object based on multiple answer questionnaire, Formamente 2016/1-2.

6. Berardo S.A. Designing a Language Learning Syllabus. 2007.

7. Corder P.S., Introducing Applied Linguistics, Penguin Books, London 1973.

8. Makhmonov L.S., Mamatkulova F.K., Berdiyarova M.B., \& Shomurodov K.E. (2021). The main causes of anemia in iron and vitamin b 12 deficiency associated with helicobacter pylori. Nveo-natural volatiles \& essential oils Journal| NVEO, 10167-10174.

9. Makhmonov L.S., Yigitov A.U., Amerova D.A., \& Temirov N.N. (2021). Coordination of treatment guidelines for iron deficiency and b12 deficiency anemia associated with helicobacter pylori. Nveo-natural volatiles \& essential oils Journal । NVEO, 10175-10182.

10. Shahram A., Umida K., \& Zarina R. (2020). Information technology's role in the study of foreign languages. Asian Journal of Multidimensional Research (AJMR), 9(3), 96-98. 